AperTO - Archivio Istituzionale Open Access dell'Università di Torino

\title{
Economics in the International Encyclopaedia of Unified Science
}

\section{This is the author's manuscript}

Original Citation:

Availability:

This version is available http://hdl.handle.net/2318/59870

since

Terms of use:

Open Access

Anyone can freely access the full text of works made available as "Open Access". Works made available under a Creative Commons license can be used according to the terms and conditions of said license. Use of all other works requires consent of the right holder (author or publisher) if not exempted from copyright protection by the applicable law. 


\section{Economics in the International Encyclopaedia of Unified Science}

\section{Giandomenica Becchio*}

\section{Introduction}

In 1922 Moritz Schlick founded a philosophical circle which was named after him, and later became better known as simply the Vienna Circle. It was a private group; its members shared the rejection of both idealism and neo-Kantianism that culminated in the advent of the new empiricism. The new-empiricist paradigm (or logical empiricism) repudiated every statement not verifiable either logically or empirically ${ }^{1}$.

During the 1930s the philosophers of the Vienna Circle pursued the ideal of a unified science (Einheitswissenschaft) as one of the paramount aims of their new empiricist approach. According to Neurath (its first promoter), Einheitswissenschaft was not a sort of "super-science" or "meta-science" (a set of methodological rules to be applied to every science); it had to be regarded as a tool able to unify scientific language, in order to avoid the many metaphysical questions that still persisted in some sciences.

In the mid 1930s, Americân philosophers like Charles W. Morris emphasized the connection between the Viennese new empiricism (or logical positivism) and American pragmatism.

Morris' pragmatism was mainly focused on the foundation of a theory of language and signs to be applied to all areas of knowledge. In Foundations of the Theory of Signs (Morris 1938) he shared the logical positivistic interpretation about analytic propositions as merely syntactical truths, having no metaphysical significance. Morris was in particular debt to Rudolph Carnap, one of the most influential philosophers of the Vienna Circle.

The Viennese and the American philosophers fought strongly against metaphysics; they believed in the unified science model; and - last but not least - they also shared a common political vision, the compatibility between democracy and socialism. Their radical philosophy, as well as their left-oriented political project, was "later rejected after the war by an [American] academic establishment that had moved to the political right" (Reisch 2005: 57).

Neurath, Carnap and Morris jointly organized the project for the International Encyclopaedia of Unified Science, which was presented at the International Congresses

\footnotetext{
* Department of Economics, University of Turin. E-mail: giandomenica.becchio@unito.it.

${ }^{1}$ According to Schlick's theory of knowledge (Schlick 1918), the aim of this new scientific paradigm was to reject any kind of metaphysics in order to find a proper logical description and definition for any empirical observation.
} 
for the Unity of Science (1934-1941) in Europe and the U.S.A (where many Austrian scholars moved, after the Anschluss in 1938)2

The International Encyclopaedia was to be targeted at the largest number of readers, but unlike other encyclopaedias, where topics followed an alphabetical order without any specific connections, the International Encyclopaedia's aim was to provide a logical interrelation among different sciences in order to unify them.

Economics had been included in the Vienna Circle's Manifesto (Hahn, Neurath and Carnap, 1929) and thereafter in the Unified Science project, but the volume on economics appeared late, in 1968, thirty years after the launch of the project, and twenty years after its definitive transfer to the U.S.A.

The aim of this paper is to show the story of economics in this project; and to illustrate how problematic was its inclusion - basically because philosophers and social scientists involved were not persuaded by the cohesion inside the discipline and its actual status of science.

\section{The International Encyclopaedia from Vienna to the USA (1928-1941)}

Between 1928 and 1937, the Vienna Circle published ten books in a collection entitled Schriften zur wissenschaftlichen Weltauffassung (Monographs on the Scientific - Conception of the World), edited by Moritz Schlick and Philipp Frank at the beginning, and later by Carnap, Frank, Hahn (until his death in 1934), and Neurath. In this collection they introduced the concept of Einheitswissenschaft (Unified Science).

In 1931, Albert Blumberg and Herbert Feigl first introduced logical positivism to an American audience and used that expression to denote the Viennese philosophical outlook. (Feigl and Blumberg 1931) ${ }^{3}$.

In 1934, Charles Morris spent some, weeks in Vienna "to make connection with members of the Wiener Kreis"4, and thereafter attended a congress in Prague where numerous Viennese, German and American philosophers had gathered: during that congress the decision to launch the International Encychlopaedia project was officially announced (Stadler 2001).

The two promoters of the project were essentially Otto Neurath in Europe (he moved from Vienna to The Hague in 1935 and, after the Nazi occupation of Holland in 1941, he escaped to England) and Charles Morris in Chicago.

Charles Morris's role became fundamental in 1934, when after the advent of the

${ }^{2}$ Among them were scholars belonging to the Vienna Circle and it is possible to speak of the "exiled Vienna Circle” (Feigl 1969; Stadler 2001; Richardson and Uebel 2007). There is quite a large body of literature on the topic. E. Craver (1986) claimed that "the most productive" immigrants were those who adapted well to the American tradition and mixed their contributions to American economics; K. Vaughn (1994) described the migration of the economists of the Austrian school; E. Timms and J. Hughes (2003) edited a book on the intellectual migration of Viennese scholars to the English-speaking world (including the UK); M. Rutherford (2004) described the relation between Columbia University and the "University in Exile" (later the Graduate Faculty for Political and Social Science of the New School), founded to accommodate the exiled German scholars.

${ }^{3}$ Feigl was one of the most prominent students of Schlick and later one of the most active members of the Vienna Circle. In 1930 he obtained a fellowship for a visiting position at Harvard (USA) where he co-authored the above-mentioned paper with Blumberg. Albert Blumberg had received his $\mathrm{PhD}$ in Vienna under the supervision of Schlick and taught at The Johns Hopkins University. ${ }^{4}$ Charles Morris to Karl Menger on July 5, 1934. Karl Menger papers, Perkins Library, Duke University.

N.B. Copia ad uso personale. Non ne è consentita la condivisione e/o la messa a disposizione al pubblico su rete pubblica o privata, sia in forma gratuita sia a pagamento. 
fascist Austrian government, difficult times began, in particular for Jewish scholars but also for those not linked with the regime in general. It was Morris who arranged to find the financial support to organize the entire Encyclopaedia project. In a letter of 28 January 1935 he requested W. Weaver (Rockefeller Foundation) to provide financial support for the unified science movement. In this letter, Morris described the movement:

I represent an international group of scientists and logicians interested in the unification of science meaning by that term not a synthesis of factual results but the analysis and systematization of the language of science. The enterprise is in no sense philosophical, if by philosophy one means more than work on the foundations of science and completion of the structure of science. (...) The three purposes of this group are 1) to unite scientists and logicians interested in the unification of the language, and secondarily the factual results of science, 2) to publish ultimately an encyclopaedia of the sciences, written for the first time in terms of a unified conceptual apparatus, 3) to act to some extent as a unified centre against the anti-scientific tendencies which threaten to limit or destroy the slowly acquired scientific habit of mind and technique ${ }^{5}$.

The correspondence between Morris and Neurath is a valid source to illustrate the genesis of the Encyclopaedia. This was intended to be a new research project based on the general aims described in the above-quoted letter and not simply an extension of the Vienna Circle's philosophical positions. As Morris pointed out in a letter of 11 November 1936 to Neurath: "I am interested in the Unity of Science movement as such, and not in any special group such as the Wiener Kreis, the pragmatists, or any other". ${ }^{6}$

Their correspondence also reveals the efforts made to involve European and American scholars in the project. In a letter of 30 March 1936, Morris announced to Neurath that the University of Chicago Press had agreed to publish the Encyclopaedia ${ }^{7}$. In the fall of 1936 Neurath travelled to Chicago in order to organize every detail for the Encyclopaedia with Morris and Carnap (who had moved to Chicago).

In the meantime, in Vienna, it was impossible to continue publishing Erkenntnis, the journal of the Vienna Circle. Many scholars belonging to the circle had moved to the United States or to England, where the Circle's ideas became increasingly widespread; and others had died (Schlick was killed in 1936) ${ }^{8}$. In 1938 the Anschluss definitively destroyed the Viennese milieu. By the late 1930s the entire Vienna Circle had resettled outside Austria.

Although there was strong initial interest in the movement, its activities were seve-

${ }^{5}$ Charles Morris Correspondence, Guide to the Unity of Science Movement Records, 1934-1968, Regenstein Library, University of Chicago: henceforth Charles Morris correspondence, Regenstein Library, University of Chicago.

${ }^{6}$ Charles Morris correspondence, Regenstein Library, University of Chicago.

${ }^{7}$ Hence the next step was to set up "special committees" for the various disciplines: Morris suggested Enriques for the history of science, Aukasiewicz for the history of logic, Carnap for logic, and Reichenbach for the methodology of logic. ${ }^{8}$ In a letter of 11 May 1936, as contributors Neurath gave Morris the names of Mannoury, Feigl, Dubislaw, Karl Menger, Radacovic, Waismann, Zilsel, and Popper and suggested to Morris that "it would be useful to use Ernst Nagel as collaborator and other young Americans".

${ }^{8}$ Erkenntnis was replaced by a new journal, published in Chicago, which Morris suggested to Neurath should be called "Journal of Unified Science". Letter from Morris to Neurath (31 May 1938) and letter from Morris to Donald Bean, head of the Chicago University Press (20 November 1938). See also Neurath to Morris (5 April 1940): "the transformation of Erkenntnis into the Journal of Unified Science is completed”, Charles Morris correspondence, Regenstein Library, University of Chicago.

N.B. Copia ad uso personale. Non ne è consentita la condivisione e/o la messa a disposizione al pubblico su rete pubblica o privata, sia in forma gratuita sia a pagamento. 
rely restricted by the outbreak of the Second World War: the Journal was suspended in 1940 and the last congress was held in 1941 at the University of Chicago. On that occasion, in his welcome speech, Morris declared:

the term unity of science serves as a slogan for the organization. The unity of science movement simply provides an occasion for co-operative attack upon all problems which concern the scientific enterprise as a whole. The nature of this enterprise, the methods science employs, the history of science, the sociology of science, the interrelations of the terms and the laws of the special sciences. There is no set of dogma which one must believe, no conclusion into which the results of cooperative endeavour must be pressed, no insistence upon unity. No one can, then, speak officially for the unity of science movement"'.

Thereafter, the Unity of Science Movement and the International Encyclopaedia project moved to Chicago, where Morris and Carnap were living and working. Furthermore, during the Second World War any organization of the movement as well as of the Encyclopaedia was interrupted for a long period; Neurath died suddenly at the end of 1945. From 1938 to 1969 twenty books (collected into two volumes) of the Encyclopaedia appeared.

\section{The place of economics at the beginning of the International Encyclopaedia}

The Manifesto of the Vienna Circle (1929) treated economics, together with history, as a social science and placed it among the group of five sciences (arithmetic, physics, geometry, biology and psychology, and the social sciences) that were to become the subject-matter of the new positivist philosophy after the "elimination of metaphysical admixtures" still present in them (Hahn, Neurath and Carnap 1929, and Neurath 1973). In 1931, Neurath claimed that History and political economy should be "merged into a single science”, namely 'sociology'.

Neurath undoubtedly had the firm intention of including economics in the Einheitswissenschaft. In a letter of 10 October 1936 about Neurath's itinerary and the people whom he was expected to meet, Morris gave a list of persons on the Faculty interested in the Encyclopaedia project, and he invited Neurath to regard Alfred Schütz, the economist, as someone that they "should consider in making assignments for the Encyclopaedia”. Nevertheless, a month later, in another letter (November 18, 1936) where Morris listed the planned 16 pamphlets making up the two volumes Foundations of the Unity of Science, economics was not included.

At the second International Congress for the Unity of Science (Paris 1935), Robert Gibrat did present a paper on economics, which he described as a complex science that must be expressed in mathematical terms, and in particular by econometric tools able to analyze statistical data (Gibrat 1936). The importance of statistics for economic analysis had always been a constant of Neurath's thought as well: for him, statistics was the sole tool required by calculation in kind (Neurath 2004: 327). Neurath himself presented a paper at the fifth International Congress for the Unity of Science (Cambridge, MA, 1939) in which he stressed the need to include economics in the unified science, although he acknowledged that it could be difficult ${ }^{10}$. In spite of Neurath's effort to include economi-

${ }^{9}$ Charles Morris correspondence, Regenstein Library, University of Chicago.

${ }^{10}$ Neurath discussed two kinds of economics: one dealing with market, money, consumption, production (where it is possible to create models in order to show real economic events); the other dealing with "the combination of different levels of lives", that would be possible in a system of

N.B. Copia ad uso personale. Non ne è consentita la condivisione e/o la messa a disposizione al pubblico su rete pubblica o privata, sia in forma gratuita sia a pagamento. 
cs in the Encyclopaedia, there was no place for it. In a letter of 23 April 1941, M. K. Hubbert discouraged Morris from including economics in the project of unifying science, comparing it to astrology and alchemy. In the same year (1941) The Development of Rationalism and Empiricism by G. De Santillana and E. Zilsel appeared as the eighth chapter of the second volume of the International Encyclopaedia ${ }^{11}$. In their volume, economics was not included: the reason was explained by Zilsen in the Introduction: political economy cannot be considered scientific unless "rational deduction and mathematics" will be used by every economists, and it won't be exposed to "selfish interests, political pressure, and wishful thinking”. He wrote:

in political economy scientific agreements could be reached only on comparatively unimportant questions; in fact, there are separate schools which do not even recognize each other. Some of them cling to experience; the results of their inquiries are collections of material rather than theories in which facts are causally explained. Others deal with nothing but laws of economy; they investigate them by means of rational analysis of a few basic concepts and construct large deductive systems based upon scanty observations (Zilsel 1941: 832-833).

Despite Neurath's idea that logical positivism should be applied to economics, during the migration of the Unified Science movement from Vienna to USA (late 1930s), there was no room for economics in the International Encyclopaedia.

\section{The International Encyclopaedia in the U.S.A (1947-1969)}

During the Second World War, the publication of the International Encyclopaedia was interrupted. At the end of the war, the project was resumed by Charles Morris and Rudolph Carnap, both in Chicago, and Philipp Frank, whose role grew increasingly important; The Unity of Science Movement planned to continue publication of the second volume of the International Encyclopaedia, which was to be concerned with the sociohumanistic sciences (Morris 1946) and ethics in particular.

In 1947, the Institute for the Unity of Science was re-founded in Ithaca, New York. The board members of the "Institute for the Unity of Science" included all the members of the old Vienna Circle who had moved to the USA: Frank, the president (Harvard), Morris (Chicago), Nagel (Columbia), Carnap (Chicago), Feigl (Minnesota), Hempel (Yale), Reichenbach (UCLA). When Frank moved to Boston, the legal head office of the Institute followed him. In 1965 Morris succeeded Frank as President of the Institute for the Unity of Science.

The Institute's purpose was:

to encourage the integration of knowledge by scientific methods, to conduct research in the psychological and sociological backgrounds of science, to compile and publish bibliographies and other forms of literature with respect of the integration of scientific knowledge, to support the international movement for the Unity of Science and to serve as a centre for the continuation of the publications of the Unity of Science movement” (Frank 1947). ${ }^{12}$

centralized planned economy without money. (Neurath 1973: 211).

${ }^{11}$ Zilsel was a Viennese scholar, member of the Gompertz Circle (which included Popper), another Viennese philosophical circle closely in contact with the Vienna Circle.

12 The manifesto of this new movement was published in Institute for the Unity of Science. From Minutes of Board of Regents, Synthese, 6:3/4 (1947-1948):158.

N.B. Copia ad uso personale. Non ne è consentita la condivisione e/o la messa a disposizione al pubblico su rete pubblica o privata, sia in forma gratuita sia a pagamento. 
In 1947, the Rockefeller Foundation started to finance the Institute for the Unity of Science, whose aim was to apply logical and empirical analysis to "hybrid fields [like] 'mathematical economics'” (Frank to Morris, 1949).

\section{Tintner's volume on economics (1968)}

Many years passed before the Board of the Unity of Science Movement made up its mind to schedule a volume on economics. In a letter of June 21, 1960 Morris wrote to Carnap that it was time to find someone able to write the volume of the Encyclopaedia dealing with economics. Jan Tinbergen was asked to write a "Mathematical Tools in Economics”, but he refused. Three years later, Gerhart Tintner, a former student of Carnap's, was chosen to write Methodology of Mathematical Economics ${ }^{13}$. The genesis of this volume was rather difficult: there were three versions. Finally, Methodology of Mathematical Economics and Econometrics appeared in $1968^{14}$.

Following the overall aim of the Unity of Science Movement, Tintner addressed his text "to a public which does not necessarily consist of economists" (Tintner 1968: vii). He maintained that economics can adopt two different methods: mathematical economics and econometrics, both of which are valid tools for raising the scientific level of economics and for including it in the ideal of unified science.

The book consisted of three chapters: Mathematical Economics, Econometrics and Welfare Economics and Economic Policy. Mathematical Economics was described as a scientific theory that "uses the logical-deductive method and derives conclusions from certain fundamental assumptions or axioms, such as rationality and profit maximization" (Tintner 1968: 14). Econometrics was described as "an important special method for the evaluation of mathematical economic models in numerical terms and for the verification of economic theories; it uses the methods of modern statistics for this purpose ... based upon applied probability” (Tintner 1968: 56). The final chapter on welfare economics and economic policy dealt mostly with the distinction between positive and normative economics and with explanation of the welfare utility function from Bergson to Arrow.

The core of Tintner's book is the Introduction, which started with a definition of economics explicitly borrowed from Robbins and Lange: "the science which studies human behaviour as a relationship between given ends and scarce means which have alternative uses (Robbins 1949: 16) or, on the other hand, as the science of administration of scarce resources in human society (Lange 1953)” (Tintner 1968: 6). Tintner explicitly considered it "deplorable" that economists "on the left and on the right" are influenced

${ }^{13}$ Some years previously, in a letter to Carnap, Tintner had proposed himself to write a monograph for inclusion in the International Encyclopaedia, but at that time the Board had hoped to obtain a monograph in the humanities from Meyer Shapiro (Columbia). Because by 1963 Shapiro had not delivered any of the material that he had promised, Morris asked Tintner if he was still in a position to consider writing the monograph he had proposed.

14 The first manuscript was refereed by Morris, who was disappointed by the first manuscript. In a letter to A. Richter (assistant director of the University of Chicago Press) he claimed that, although "portions of the Tintner's monograph will not be followed in detail by the general reader", the series is too weak in the social sciences area; hence "it is important to have a monograph which strengthens this area” (October 6, 1965).

Tintner's second version of his manuscript disappointed Carnap, who wrote to Morris: “although far from really satisfactory, still the best we can get from him; and there will be some readers who can benefit from it” (June 6, 1966).

N.B. Copia ad uso personale. Non ne è consentita la condivisione e/o la messa a disposizione al pubblico su rete pubblica o privata, sia in forma gratuita sia a pagamento. 
by ideology and "have sometimes illegitimately presented value judgments as scientific truth" (Ibid.). According to Tintner, even if economics like any other social science deals with human action, it is fundamental to keep the ideological motivations of a scientist separated from any possible scientific result. According to Tintner, this goal was far from being achieved in economics because of the ideological bias of most economists, hence he suggested that the only method for transforming economics into an objective science was the introduction of mathematical tools and statistics.

Tintner specified that the use of mathematics in economic theory had grown increasingly common in previous decades and had become the tool best suited to "theoretical economics", even if "the bulk of the results of theoretical economics has been achieved without mathematical means" (he recalled the struggle of theoretical economics against the German historical school and the American institutionalism), and he stated that "mathematical economics and econometrics are the only methods for the study of problems in economics". The aim of economics, according to Tintner, is "to construct fundamental models to apply to concrete economic problems"; he stressed the need to bridge the gap between theoretical concepts and empirical observations. Quoting Carnap and Popper, Tintner recalled the neo-positivist philosophical approach that emphasized the unity of scientific method in the natural and social sciences, and he maintained that economics could be included in this project only when it used mathematics or/and applied it to empirical cases in an econometric sense, because only mathematical economics and econometrics could be regarded as theoretical economics at this stage of the discipline's development.

\section{Concluding remarks}

Born within Viennese logical positivism in the early 1930s, the ideal of building a general methodology, able to free all the sciences from metaphysics and solve real problems, attracted some American scholars. When Germany and Austria under the Nazi regime the entire Viennese movement were forced to relocate (not just metaphorically), mostly to the USA in the late 1930s, where the project of the International Encyclopaedia was strengthened and the Unity of Science Movement was founded. Viennese logical positivists and American pragmatists shared a left-oriented or liberal political position: the idea of a unified science was a sort of "methodological democratization" of the science as a whole. The urgency to include economics was essential from a theoretical as well as political point of view.

The initial plan of the Encyclopaedia was set by Morris and Neurath between 1935 and 1936, when European regimes were collapsing under the right-wing dictatorships. Foundations of the Unity of Science was published between 1938 and 1969, and consisted of twenty monographs forming only two of the 200 planned volumes. As Morris wrote to Frank (2 June 1965): "it has been a fine enterprise, though only a fragment of what Neurath had planned”.

Economic theory had its own place into this ambitious project: as one of Neurath's main interests it was included in the initial program of logical positivism. Nevertheless, under the direction of Morris and Carnap, economic theory was set aside for about twenty years. In early 1960s, Tintner's volume on economics was finally scheduled: mathematical economics and econometrics were recognized as the final and proper application of logical positivism to economics as a science.

Economics reached a "positive" stage, when it was formalized, based on quantitative data, and when - from a methodological point of view - it became a "neutral" science à la Robbins-Pareto. This "positivistic" economics became the mainstream economics while 
the political aspect of economics was set aside. It does not seem coincidental that this happened in the USA during the Cold War.

\section{References}

Craver E. (1986). The Emigration of the Austrian Economists, History of Political Economy, 18(1): 1-32.

Dawson J.W. and K. Sigmund (2006). Gödel's Vienna, The Mathematical Intelligencer, 28: 44-53.

Feigl H. (1969). The Wiener Kreis in America. In Fleming and Baylin, (eds.)(1969): 57-93.

Fleming D. and B. Baylin, (eds.)(1969). The Intellectual Migration, Cambridge (Mass), Harvard University Press.

Frank P. (1948). The Institute for the Unity of Science, its Background and its Purpose. Synthese, 6 (3/4): 160-167.

Gibrat R. (1936). La Science économique. Methodes et philosophie. In Actes du congrès international de philosophie scientifique, Paris: Hermann \&C editeurs: 22-31.

Hahn H., O. Neurath, and R. Carnap (1929). Wissenschaftliche Weltauffassung. Der Wiener Kreis. Wien: Arthur Wolf Verlag, In Neurath (ed.)(1973): 299-318.

Janik A. and S. Toulmin (1996[1973]). Wittgenstein's Vienna, Chicago, Ivan R. Dee, Publisher.

Lange O. (1942). The Foundation of Welfare Economics. Econometrica, 10(3-4): 215-228.

Leonard R. (1998). Ethics and the Excluded Middle. Karl Menger and the Social Science in Interwar Vienna. Isis, (89): 1-26.

Menger K. (1994). Reminiscences of the Vienna Circle and the Mathematical Colloquium, Dordrecht, Kluwer Academic Publishers.

Menger K. (2009). Unexplored Dimension: Karl Menger on Economics and Philosophy (1923-1938), Bingley (UK), Emerald Group Publishing.

Menger Karl Papers, Perkins Library, Duke University: Durham, N. C.

Morris C. (1938). Foundations of the Theory of Signs, Chicago, University of Chicago Press.

Morris C. (1946). The Significance of Unity of Science Movement. International Phenomenological Society, 6(4): 508-515.

Morris C. (1960). On the History of the International Encyclopaedia of Unified Science. Synthese, 12 (4): 517-521.

Morris Charles, Correspondence, Regenstein Library, University of Chicago.

Nemeth E. and F. Stadler (1996)(eds.) Encyclopedia and Utopia: The Life and Work of Otto Neurath (1882-1945), Wien: Kluwer Academic Publisher.

Neurath O. (1969[1944]). Foundations of the Social Sciences, Chicago, University of Chicago Press.

Neurath O. (ed.)(1973). Empiricism and Sociology, Dordrecht, Reidel.

Neurath O. (2004). Economic Writings. Selection 1904-1945. Dordrecht, Kluwer Academic Publishers.

Reisch G. (2005). How the Cold War Transformed Philosophy of Science. To the Icy Slope of Logic, Cambridge, Cambridge University Press.

Richardson A. and T. Uebel (2007). The Cambridge Companion to Logical Empiricism, Cambridge, Cambridge University Press.

Rutherford M. (2004). Institutional Economics at Columbia University. History of Political Economy, 36(1): 31-75.

Schlick M. (1918). Allgemeine Erkenntnislehre, Berlin, Springer.

N.B. Copia ad uso personale. Non ne è consentita la condivisione e/o la messa a disposizione al pubblico su rete pubblica o privata, sia in forma gratuita sia a pagamento. 
Soulez A. (1996). Otto Neurath or the Will to Plan. In Nemeth and Stadler (1996)(eds.): 221232.

Stadler F. (2001). The Vienna Circle. Studies in the Origins, Development, and Influence of Logical Empiricism, Vienna-New York, Springer.

Timms E. and J. Hughes (eds.)(2003). Intellectual Migration and Cultural Transformation. Refugees from National Socialism in the English-Speaking World, Vienna-New York, Springer.

Tintner G. (1968). Methodology of Mathematical Economics and Econometrics. In The International Encyclopaedia of Unified Science, 2 (6), Chicago, University of Chicago Press.

Vaughn K. (1994). Austrian Economics in America: The Migration of a Tradition, Cambridge, Cambridge University Press.

\section{ABSTRACT}

The International Encyclopaedia of Unified Science, 1938-1969 (promoted, above all, by Otto Neurath in Vienna and Charles Morris in the United States) was based on the feasibility of building a "unified science" and it was carried on through the publication of a special "encyclopaedia" to show the meaning of this philosophical project.

The purpose of this paper is to reconstruct, mainly from a historical point of view, the development of economic theory within this project: from the role of economics inside the Vienna Circle in the 1930s (more specifically in Neurath's perspective) to the meaning of economics in Tintner's volume, published in 1968.

The role of economics inside the International Encyclopaedia is a part of the story of "the building of the economic "mainstream" (a quantitative and formalist approach to economic issues) during the 1950s and the 1960s in the USA.

Jel Classification: A11, A12, B25, B40

Keywords: unified science, economics, philosophy, Neurath, Tintner

N.B. Copia ad uso personale. Non ne è consentita la condivisione e/o la messa a disposizione al pubblico su rete pubblica o privata, sia in forma gratuita sia a pagamento. 